\title{
Predaceous Water Beetles (Coleoptera: Adephaga: Dytiscidae, Gyrinidae) Collected Along the Horton and Thelon Rivers in the Arctic Central Barrens of Canada
}

\author{
Helena V. ShaVERDO ${ }^{1}$ and Donna J. GiBERSON ${ }^{2}$ \\ ${ }^{1}$ Department of Entomology, 213 Animal Science/Entomology Building, University of Manitoba, Winnipeg, Manitoba R3T 2N2 \\ Canada \\ ${ }^{2}$ Department of Biology, University of Prince Edward Island, Charlottetown, Prince Edward Island C1A 4P3 Canada
}

Shaverdo, Helena V., and Donna J. Giberson. Predaceous water beetles (Coleoptera: Adephaga: Dytiscidae, Gyrinidae) collected along the Horton and Thelon rivers in the Arctic Central Barrens of Canada. Canadian Field-Naturalist 118(3): 425-433.

Predaceous water beetles were collected during expeditions along two northern Canadian rivers during 2000 and 2002. Twelve species of Dytiscidae (including 11 named species and one additional genus identified from a larva) and one species of Gyrinidae are recorded from 20 sites along the Horton and Thelon rivers in the Central Barrens area of the Canadian Arctic. These records represent an extension of the distributions of four species to the northeast in the Northwest Territories (NWT), and two species to the northwest in Nunavut (NU). Oreodytes sanmarkii is reported for NWT and for the mainland of NU for the first time. Ilybius erichsoni, Hydroporus geniculatus, and Gyrinus opacus are reported for NU for the first time. Five species were recorded for the first time from the Southern Arctic ecozone, and one from the Taiga Shield ecozone. The majority of specimens were collected in habitats that were consistent with those previously known for each species.

Key Words: Insecta, Coleoptera, Adephaga, Dytiscidae, Gyrinidae, predaceous water beetles, faunistics, river, Northwest Territories, Nunavut, Arctic Central Barrens.

The Central Barrens area of the Canadian Arctic is a vast and very sparsely populated area dominated by arctic tundra, scattered clumps of taiga vegetation, large lakes, and rivers. The inaccessibility of the region has meant that the area has been poorly collected for all insect groups (Currie et al. 2000), including predaceous water beetles. Only three surveys have been conducted on aquatic Adephaga in the Yukon, Alaska, and the eastern Canadian Arctic (Alarie and Maire 1991; Larson 1991, 1997), though data on this group of Coleoptera in arctic and subarctic regions can also be found in Larson and Roughley (1991), Roughley (1991), Anderson (1997), and Larson et al. (2000). Recently a series of expeditions were mounted to explore the aquatic insect fauna along large river systems on the treeless barrens of the mainland Canadian Arctic zone (Currie et al. 2000, 2002). The objective of this paper is to report on the predaceous water beetles collected from habitats in and near the Horton River Northwest Territories (NWT) and the Thelon River, NWT and Nunavut (NU), and present faunistic and habitat data from the collections.

\section{Methods}

Two expeditions were made by DJG and colleagues from various institutions to northern Canadian rivers during 2000 and 2002 (Figure 1). Expedition members flew in to upstream sections of the Horton and Thelon rivers in NWT and travelled downriver by canoe, stopping frequently to sample habitats along the linear corridor of each river. Aquatic sampling was carried out using a D-frame kick net with a $200 \mu \mathrm{m}$ mesh. In flowing water habitats, the net was placed into the stream and the substrate disturbed by kicking or by moving rocks by hand, and the dislodged insects were carried into the net by the current. In areas with little or no flow, the substrate was disturbed as above, and then the net was drawn through the water by hand to catch any dislodged insects. Insects were sorted alive from the substrate materials on site, and preserved in $80 \%$ ethanol. Predaceous water beetles were not specifically targeted in the study, but those that were collected (61 adults and 6 larvae) were examined by HVS. Collection records were compared to the maps and distribution table in Larson et al. (2000) to determine whether any of them represented range extensions among the provinces and ecozones. The document A National Ecological Framework for Canada (Ecological Stratification Working Group 1995) was consulted for the classification of Canada's ecological regions. Collecting Permits were obtained from the Aurora Research Institute (Inuvik, NWT) and the Nunavut Research Institute (Iqaluit, NU) to carry out the research. Voucher specimens have been deposited in the collections of the Wallace Museum (University of Manitoba) and the Royal Ontario Museum, and in the private collection of D. J. G.

\section{Study Site and Sampling Regime}

The Horton River begins west of Horton Lake, which is located north of Great Bear Lake in the Northwest Terriories of Canada (Figure 1). The river, which has 


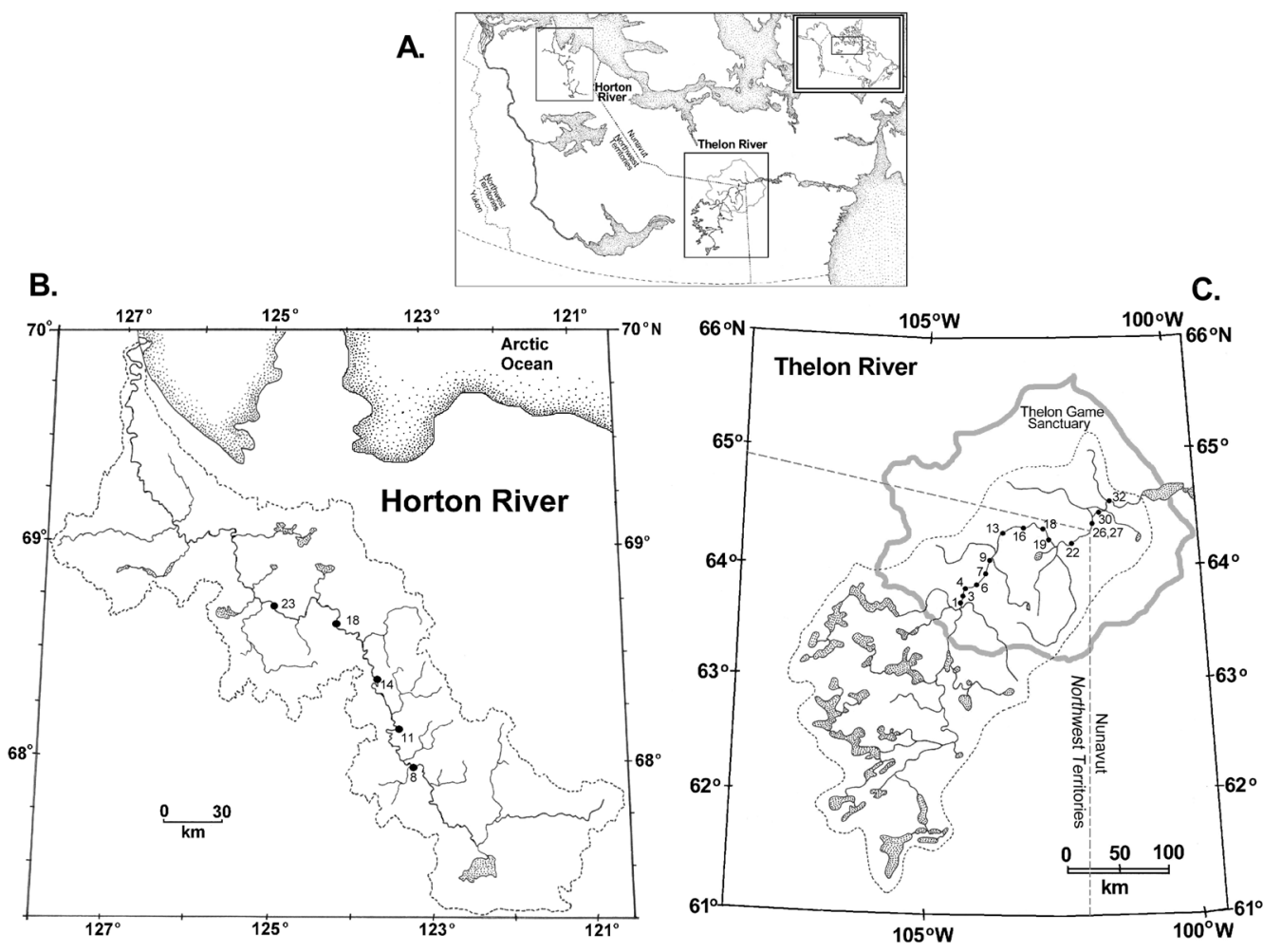

FIGURE 1. Location of study area (A), including the Horton River (B) and Thelon River (C) showing sample sites. The fine dashed line indicates the watershed boundary upstream of the lowest sampled site for both watersheds. The grey border on the Thelon Watershed map indicates the boundaries of the Thelon Game Sanctuary. Site co-ordinates are given in Table 1.

a drainage basin area of approximately $26680 \mathrm{~km}^{2}$ and a total length of $\approx 800 \mathrm{~km}$, runs entirely in the Southern Arctic Ecozone. Expedition members collected over a $700 \mathrm{~km}$ stretch of the river from Horton Lake to the Arctic Ocean. The river flows over limestone-dominated substrates in its upper reaches, where it is characterized by relatively high $\mathrm{pH}(>8.0)$ and specific conductance $(>150 \mu \mathrm{S} / \mathrm{cm})$. In its lower reaches, the river flows through the Smoking Hills, a region containing lignite and magnesium deposits which spontaneously ignite when exposed to air (for example, during bank slumping during summer). These result in "smoke holes" as smoke pours from places where the coal is burning underground, and the water draining these sites is profoundly affected by the geology. Tributaries and ponds in this region were highly acidic (some with $\mathrm{pH}$ values $<2.5$ ), and acid runoff in this area resulted in a decline in river $\mathrm{pH}$ to approximately neutral values. The river is clear and swift-flowing for most of its length, but becomes muddy and meandering in its lower portion. Sampling was carried out in 37 sites on or near the river between 17 July and $8 \mathrm{Au}-$ gust 2000. Predaceous water beetles were collected from 5 of the 37 sites along the river, corresponding to sampling sites $8,11,14,18$, and 23 of the larger Horton River survey; all were located in the middle section, which was clear and swift-moving (Figures 1b, 2; see Table 1 for descriptions of each site).

The Thelon River begins near Lynx Lake, to the east of Great Slave Lake (Figure 1). The river flows $\approx 900 \mathrm{~km}$ from Lynx Lake to Baker Lake (which exits via Chesterfield Inlet to northern Hudson Bay to the east) and drains a total area of $\approx 240000 \mathrm{~km}^{2}$. The upper portions of the Thelon River are in the Taiga Shield ecozone, then the river flows into the Southern Arctic ecozone. Expedition members flew into the junction of the Hanbury and Thelon rivers, and collected along a $300 \mathrm{~km}$ stretch of the Thelon River located within the bounds of the Thelon Game Sanctuary (Figure 1c). The part of the river covered in this survey (i.e., upstream of Beverly Lake, NU) drains an area of $71470 \mathrm{~km}^{2}$. The river corridor upstream of the study area consists of large numbers of lakes, waterfalls, and rapids, but in the study area itself, the river meanders over an ancient glacial lake bottom. At this point, the river is wide and slow moving and dominated by sandy or sand/silt-embedded cobble substrates. Surrounding relief is very low except in a few spots, 


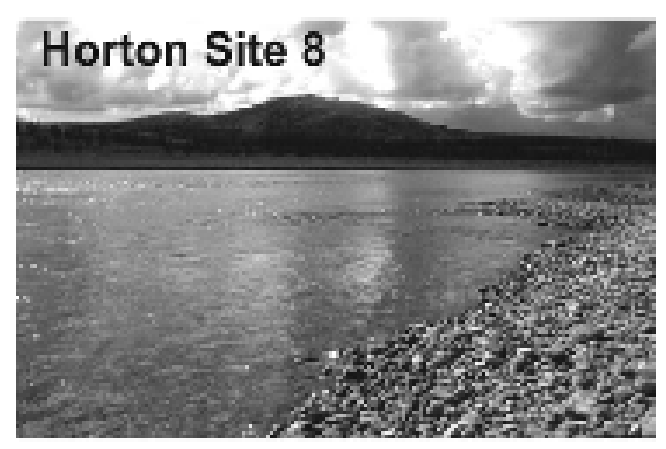

\section{Horton Site 11}
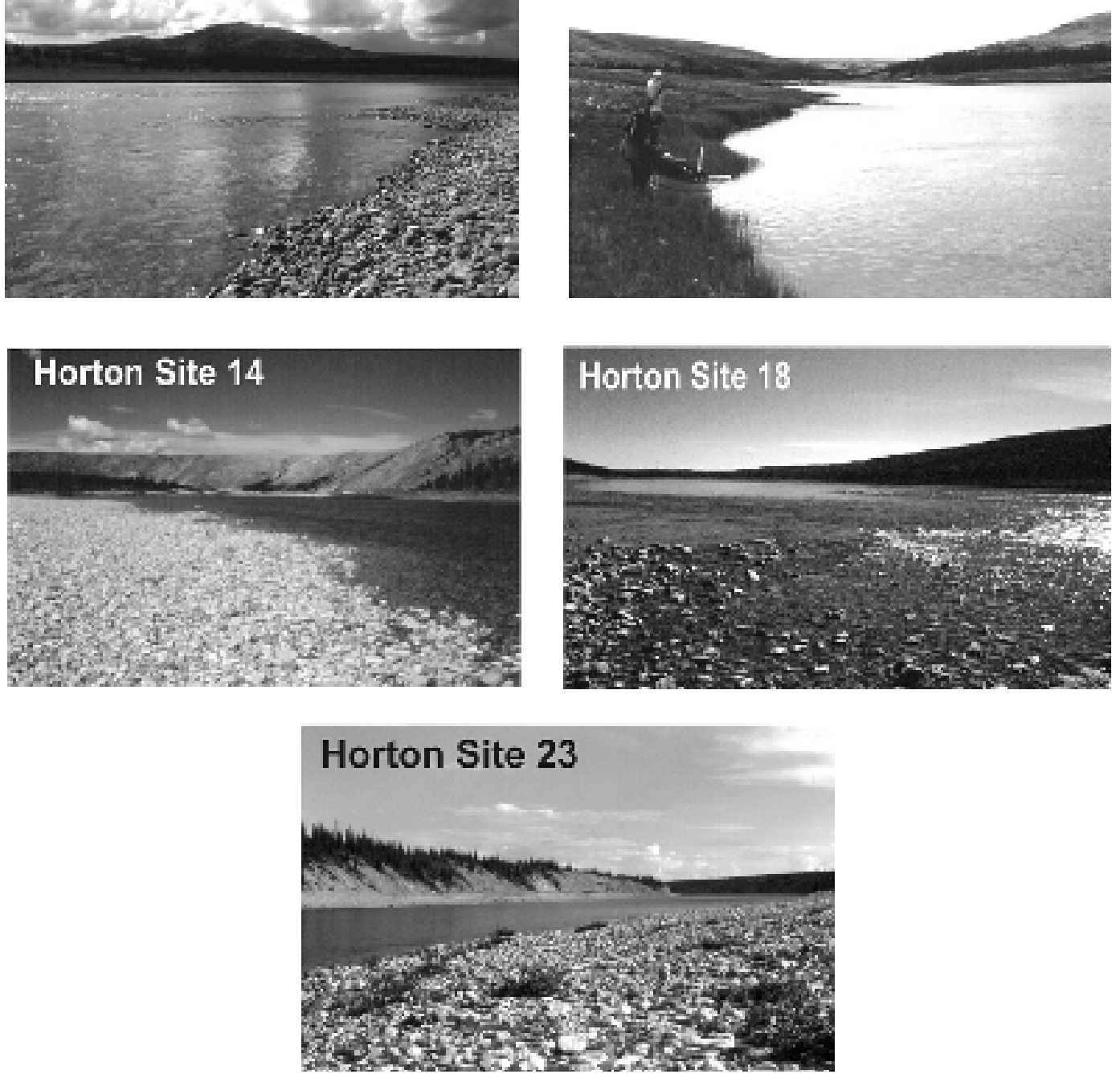

FIGURE 2. Study sites along the Horton River where predaceous water beetles were collected, July/August 2000 (compare to Figure 1B for site locations).

where low hills, boulders, and more rapid flow can be found. Most of the river flows through open tundra, but a small stretch in the upper third of the study area $(\approx 65 \mathrm{~km})$ is located in a remnant spruce and larch forest known as the "Thelon Oasis". The $\mathrm{pH}$ and specific conductance values were quite low, especially in comparison with the Horton River, with $\mathrm{pH}$ values generally around 6.0 , and specific conductance values $\approx 10 \mu \mathrm{S} / \mathrm{cm}$ for main river sites. $\mathrm{pH}$ and conductivity values for tributaries and tundra pools were more variable, however. Sampling was carried out at 34 sites on or near the river between between 29 June and 11 July 2002. Predaceous water beetles were collected from 15 of the 34 sites, representing a combination of river and pool sites corresponding to sites $1,3,4$, $6,7,9,13,16,18,19,22,26,27,30$, and 32 of the larger Thelon River survey (Figures 1c, 3; see Table 1 for descriptions of each site).

\section{Results and Discussion}

Oreodytes laevis (Kirby) and O. sanmarkii (Sahlberg) were the two most common species found in our northern rivers survey, and were also the only species found in both rivers (Table 1). Oreodytes laevis accounted for 26 of the 61 adults collected (>40\%) and was found in eight of the 20 sites where water beetles were found. 

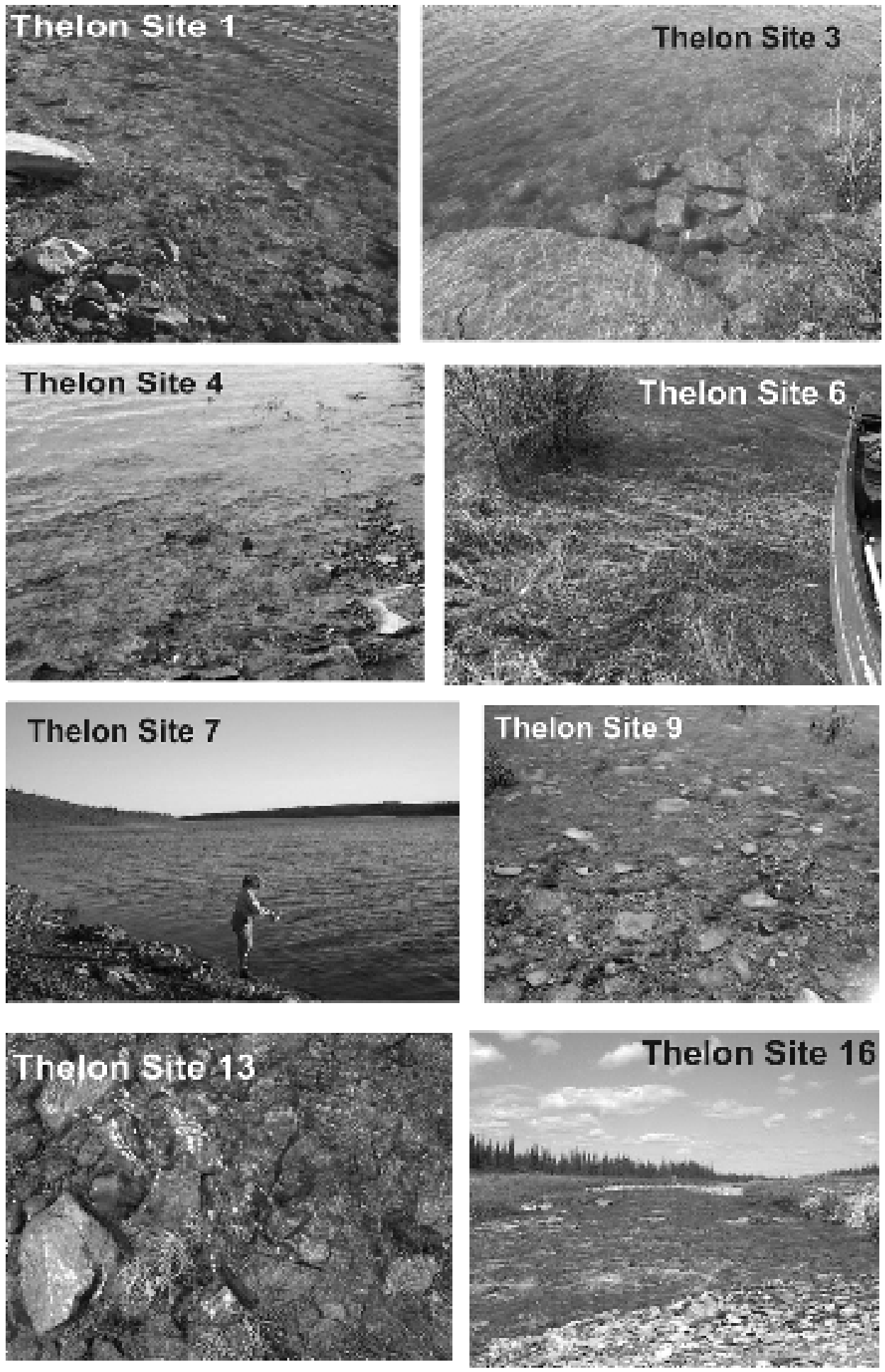

FIGURE 3a. Study sites along the upper reaches of the Thelon River where predaceous water beetles were collected, July/ August 2000 (compare to Figure 1C for site locations). 


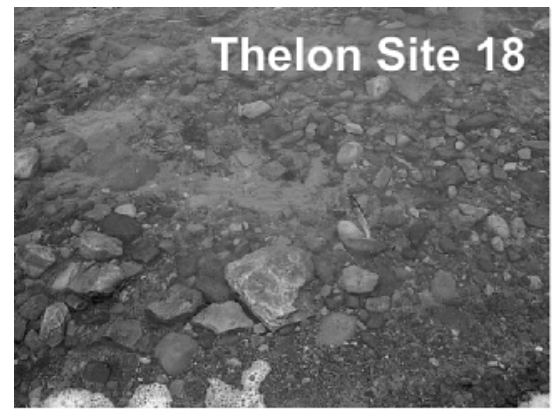

Thelon Site 22

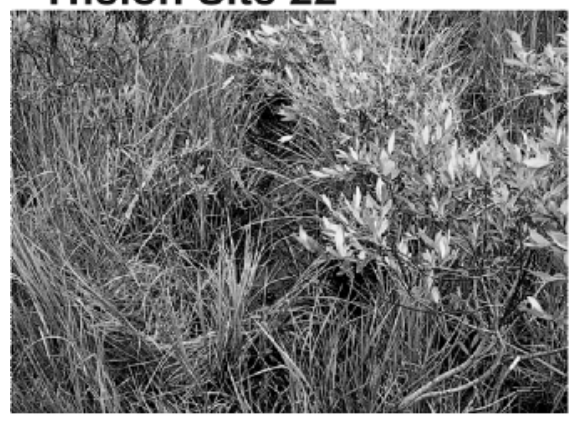

\section{Thelon Site 27}

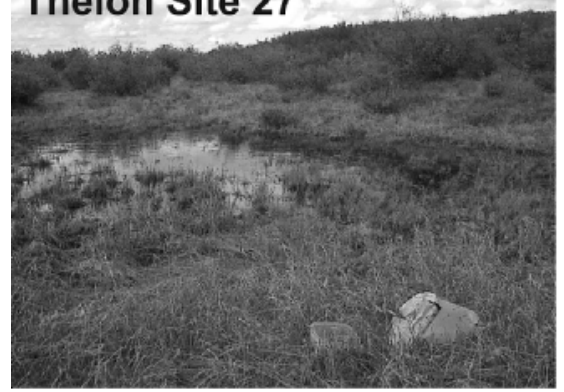

\section{Thelon Site 19}

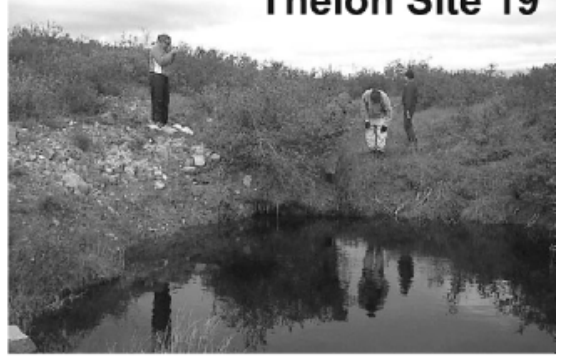

\section{Thelon Site 26}

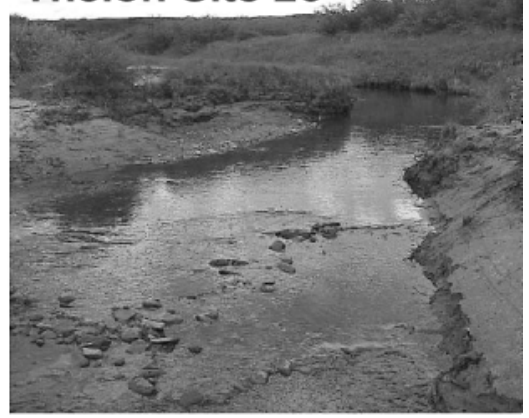

\section{Thelon Site 30}

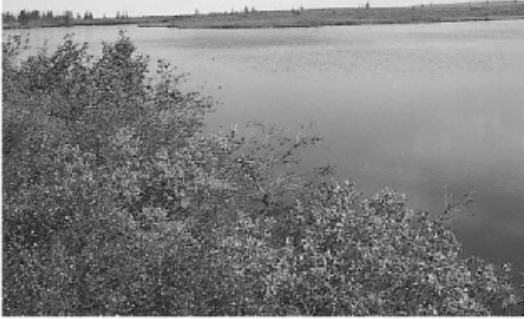

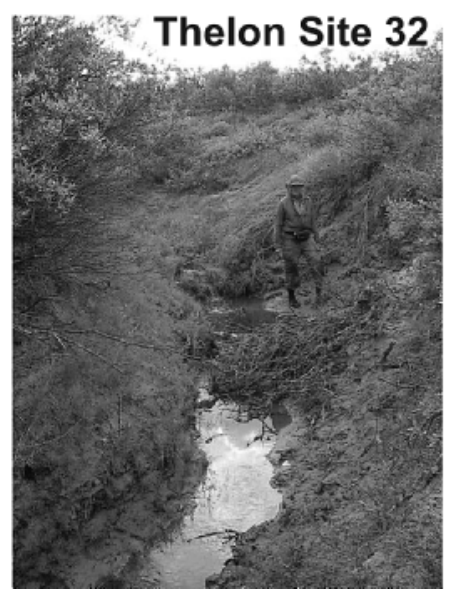

FIGURE 3b. Study sites along the lower reaches of the Thelon River where predaceous water beetles were collected, July/August 2000 (compare to Figure 1c for site locations). 
TABLE 1. Distribution and abundance of predaceous water beetles collected along the Horton and Thelon Rivers. All species were collected in the main branch of the rivers except where specifically indicated. All species were in the family Dytiscidae except Gyrinis opacus which was in the family Gyrinidae.

\begin{tabular}{llll}
\hline \hline Site $\quad$ Coordinates / Date Site Details & Species & Specimens
\end{tabular}

\section{Horton River, NWT}

$8 \quad 67^{\circ} 59^{\prime} 24.5^{\prime \prime} \mathrm{N}$ $123^{\circ} 13^{\prime} 55.5^{\prime \prime} \mathrm{W}$ 20 July 2000

$11 \quad 68^{\circ} 09^{\prime} 29^{\prime \prime} \mathrm{N}$ $123^{\circ} 22^{\prime} 44.9^{\prime \prime} \mathrm{W}$ 22 July 2000

$68^{\circ} 23^{\prime} 31.5^{\prime \prime} \mathrm{N}$

$123^{\circ} 38^{\prime} 03.4^{\prime \prime} \mathrm{W}$ 23 July 2000

$68^{\circ} 39^{\prime} 3.18^{\prime \prime} \mathrm{N}$ $124^{\circ} 08^{\prime} 53.0^{\prime \prime} \mathrm{W}$ 25 July 2000

$68^{\circ} 44^{\prime} 19.9^{\prime \prime} \mathrm{N}$

$124^{\circ} 59^{\prime} 0.8^{\prime \prime} \mathrm{W}$

28 July 2000

\section{Thelon River, NWT}

$1 \quad 63^{\circ} 38^{\prime} 04.8^{\prime \prime} \mathrm{N}$ $104^{\circ} 32$ '18.6”W 29 June 2002

$63^{\circ} 42^{\prime} 04.4^{\prime \prime} \mathrm{N}$ $104^{\circ} 25^{\prime} 26.6^{\prime \prime} \mathrm{W}$ 30 June 2002

$4 \quad 63^{\circ} 48^{\prime} 22^{\prime \prime} \mathrm{N}$ $104^{\circ} 18^{\prime} 21.1$ 'W 30 June 2002

$63^{\circ} 49^{\prime} 58.4$ 'N $104^{\circ} 06^{\prime} 20.9^{\prime \prime} \mathrm{W}$ 1 July 2002

$7 \quad 63^{\circ} 55^{\prime} 02.7^{\prime \prime} \mathrm{N}$ $103^{\circ} 56^{\prime} 59.5^{\prime \prime} \mathrm{W}$ 1 July 2002

$64^{\circ} 02^{\prime} 13.2^{\prime \prime} \mathrm{N}$ $103^{\circ} 51^{\prime} 41.8^{\prime \prime} \mathrm{W}$ 2 July 2002 $64^{\circ} 17^{\prime} 01.8^{\prime \prime} \mathrm{N}$ $103^{\circ} 33^{\prime} 22.4^{\prime \prime} \mathrm{W}$ 3 July 2002 $64^{\circ} 19^{\prime} 18.6 ” \mathrm{~N}$ $103^{\circ} 19^{\prime} 15.7^{\prime \prime} \mathrm{W}$ 4 July 2002 cobble dominated riffle and shore section, where river slowed and flowed through a broad valley; $\mathrm{pH}$ : 8.3 ; conductivity: $150 \mu \mathrm{S} / \mathrm{cm}$; temp.: $15^{\circ} \mathrm{C}$

slow, weedy shoreline area along the main channel of the river (fill in from logbook); $\mathrm{pH}: 8.2$; conductivity: $180 \mu \mathrm{S} / \mathrm{cm}$; temp.: $10.5^{\circ} \mathrm{C}$

backwater zone and a riffle, from a portion of the river in a narrow valley surrounded by high limestone cliffs; $\mathrm{pH}: 8.2$; conductivity: $180 \mu \mathrm{S} / \mathrm{cm}$; temp.: $12^{\circ} \mathrm{C}$

the river is a series of very shallow

flats and riffles; temp.: $12^{\circ} \mathrm{C}$

canyon/white-water area of the river, deep bedrock pools and fast riffles; at camp spot no obvious riffles though water moving very fast; sampled from shore; temp.: $17^{\circ} \mathrm{C}$

relatively slow and wave washed section near shore, in silt/sand embedded cobble; $\mathrm{pH}$ : 6.2; conductivity: $10 \mu \mathrm{S} / \mathrm{cm}$; temp.: $11^{\circ} \mathrm{C}$

rocky shore with fairly strong current, and in backwater pools behind large boulders; $\mathrm{pH}$ : 6.2; conductivity:

$10 \mu \mathrm{S} / \mathrm{cm}$; temp.: $11^{\circ} \mathrm{C}$

slow section near shore, with cobble substrate embedded in sand and silt; $\mathrm{pH}$ : 6.2; conductivity: $10 \mu \mathrm{S} / \mathrm{cm}$; temp.: $10.5^{\circ} \mathrm{C}$

submerged grasses in slow current near shore, $10 \mathrm{~m}$ upstream of a tributary entering from the south; $\mathrm{pH}$ : 6.2 ; conductivity: $40 \mu \mathrm{S} / \mathrm{cm}$; temp.: $14^{\circ} \mathrm{C}$

cobble and silt substrate near shore where main river narrowed and became swift flowing, even near shore; $\mathrm{pH}$ : 6.2; conductivity: $10 \mu \mathrm{S} / \mathrm{cm}$; temp.: $11^{\circ} \mathrm{C}$

at Hornby Point; well embedded cobble in fast, shallow riffle near shore; $\mathrm{pH}$ : 6.1; conductivity: $10 \mu \mathrm{S} / \mathrm{cm}$; temp.: $12^{\circ} \mathrm{C}$

cobble substrate in fast water in main channel, plus slower water near shore; pH: 6.3; conductivity: $30 \mu \mathrm{S} / \mathrm{cm}$; temp.: $13^{\circ} \mathrm{C}$ unnamed tributary entering Thelon River from forest to the north; riffle with large clean cobble substrate; $\mathrm{pH}$ : 7.6; conductivity: $40 \mu \mathrm{S} / \mathrm{cm}$; temp.: $16^{\circ} \mathrm{C}$

river wide and lake-like; wave-washed area, in cobble substrate well embedded in sand; pH: 6.3 ; conductivity: $10 \mu \mathrm{S} / \mathrm{cm}$; temp.: $13.5^{\circ} \mathrm{C}$

$\begin{array}{lc}\begin{array}{l}\text { Oreodytes laevis } \\ \text { (Kirby) }\end{array} & 1 \% \\ \begin{array}{l}\text { Oreodytes sanmarkii } \\ \text { Sahlberg }\end{array} & 1 \sigma^{\circ} \\ \text { Oreodytes sanmarkii } & 1 \sigma^{\circ}\end{array}$

Oreodytes laevis

Oreodytes sanmarkii $10^{\pi}$

Oreodytes sanmarkii

Oreodytes sanmarkii

Oreodytes laevis

$20^{\circ} 0^{7}$

$3 ㅇ ㅜ$

Oreodytes sanmarkii

10

2 우

Oreodytes laevis

$50^{7} 0^{\circ}$

1 ㅇ

Oreodytes laevis

$10^{\prime \prime}$

Hygrotus novemlineatus

1 ㅇ

(Stephens)

Oreodytes laevis

$30^{\circ} 0^{\pi}$

4 우우

Stictotarsus griseostriatus

10

(DeGeer)

Oreodytes laevis

1 ○’, 1 ㅇ

Stictotarsus griseostriatus

1 ㅇ

Oreodytes sanmarkii

10

Oreodytes laevis

1 우, 1 우 
TABLE 1 (continued). Distribution and abundance of predaceous water beetles collected along the Horton and Thelon Rivers. All species were collected in the main branch of the rivers except where specifically indicated. All species were in the family Dytiscidae except Gyrinis opacus which was in the family Gyrinidae.

\begin{tabular}{|c|c|c|c|c|}
\hline Site & Coordinates / Date & Site Details & Species & Specimens \\
\hline 19 & $\begin{array}{l}64^{\circ} 10^{\prime} 46.1^{\prime \prime} \mathrm{N} \\
102^{\circ} 36^{\prime} 58.1^{\prime \prime} \mathrm{W} \\
6 \text { July } 2002\end{array}$ & $\begin{array}{l}\text { small brown-water tundra pools above the } \\
\text { river on north, pools draining to each other } \\
\text { and seeping to the river; overhanging vegetation, } \\
\text { undercut banks, stony bottom; pH: } 6.0 \text {; } \\
\text { conductivity: } 20 \mu \mathrm{S} / \mathrm{cm} \text {; temp.: } 14^{\circ} \mathrm{C}\end{array}$ & $\begin{array}{l}\text { Hydroporus appalachius } \\
\text { Sherman } \\
\text { Agabus confines } \\
\text { (Gyllenhal) } \\
\text { Ilybius erichsoni } \\
\text { (Gemminger } \\
\text { and Harold) }\end{array}$ & 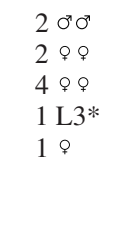 \\
\hline 22 & $\begin{array}{l}64^{\circ} 11^{\prime} 05.4{ }^{\prime \prime} \mathrm{N} \\
102^{\circ} 19^{\prime} 06.9^{\prime \prime} \mathrm{W} \\
7 \text { July } 2002\end{array}$ & $\begin{array}{l}\text { unnamed tributary seep entering the river } \\
\text { from the north and small brown-water tundra } \\
\text { pools surrounded by willows, shorelines with } \\
\text { sphagnum and grass; pH: } 5.7 \text {; conductivity: } \\
50 \mu \mathrm{S} / \mathrm{cm} \text {; temp.: } 9^{\circ} \mathrm{C}\end{array}$ & Agabus sp. & $2 \mathrm{~L} 3 *$ \\
\hline \multicolumn{5}{|c|}{ Thelon River, NU } \\
\hline 26 & $\begin{array}{l}64^{\circ} 19^{\prime} 13.2^{\prime \prime} \mathrm{N} \\
101^{\circ} 50 ' 11.1^{\prime \prime} \mathrm{W} \\
8 \text { July } 2002\end{array}$ & $\begin{array}{l}\text { unnamed tributary entering the river from the } \\
\text { north; cobble substrate in riffle area of the stream; } \\
\text { pH: } 6.5 \text {; conductivity: } 10 \mu \mathrm{S} / \mathrm{cm} \text {; temp.: } 11^{\circ} \mathrm{C}\end{array}$ & Oreodytes sanmarkii & 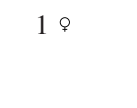 \\
\hline 27 & $\begin{array}{l}64^{\circ} 19^{\prime} 13.2^{\prime \prime} \mathrm{N} \\
101^{\circ} 50 ' 11.1^{\prime \prime W} \\
8 \text { July } 2002\end{array}$ & $\begin{array}{l}\text { small brown-water tundra pond beside site } 26 \text {; } \\
\text { much submerged and decaying vegetation (grass); } \\
\text { pH: } 6.0 \text {; conductivity: } 10 \mu \mathrm{S} / \mathrm{cm} \text {; temp.: } 15^{\circ} \mathrm{C}\end{array}$ & $\begin{array}{l}\text { Hydroporus geniculatus } \\
\text { Thomson } \\
\text { Ilybius erichsoni }\end{array}$ & $\begin{array}{l}10^{\pi} \\
10^{\pi} \\
2 \mathrm{~L}^{*}\end{array}$ \\
\hline \multirow[t]{2}{*}{30} & $\begin{array}{l}64^{\circ} 26^{\prime} 15^{\prime \prime} \mathrm{N} \\
101^{\circ} 43^{\prime} 55.1^{\prime \prime} \mathrm{W} \\
9 \text { July } 2002\end{array}$ & $\begin{array}{l}\text { large tundra pond on southern bank above the } \\
\text { river, with overhanging willows and soft bottom } \\
\text { substrates; pH: } 6.0 \text {; conductivity: } 10 \mu \mathrm{S} / \mathrm{cm} \text {; } \\
\text { temp.: } 12^{\circ} \mathrm{C}\end{array}$ & $\begin{array}{l}\text { Stictotarsus griseostriatus } \\
\text { Agabus arcticus } \\
\text { (Paykull) } \\
\text { Rhantus sp. } \\
\text { Gyrinus opacus Sahlberg }\end{array}$ & $\begin{array}{l}1 \text { o } \\
1 \text { o } \\
6 \text { ९ } ~ \\
1 \mathrm{~L} 2 * \\
1 \stackrel{9}{\circ}\end{array}$ \\
\hline & $\begin{array}{l}64^{\circ} 32^{\prime} 25.2^{\prime \prime} \mathrm{N} \\
101^{\circ} 24^{\prime} 48.9^{\prime \prime} \mathrm{W} \\
10 \text { July } 2002\end{array}$ & $\begin{array}{l}\text { unnamed small tributary entering the river } \\
\text { from the south - small pools and seeps between } \\
\text { the pools; overhanging vegetation; } \mathrm{pH}: 6.2 \text {; } \\
\text { conductivity: } 20 \mu \mathrm{S} / \mathrm{cm} \text {; temp.: } 14^{\circ} \mathrm{C}\end{array}$ & $\begin{array}{l}\text { Hydroporus morio } \\
\text { Aubé } \\
\text { Agabus thomsoni } \\
\text { (Sahlberg) }\end{array}$ & $\begin{array}{l}3 \text { \% } \\
1 \text { ণ } 1 \text { \% }\end{array}$ \\
\hline
\end{tabular}

Note: * L3 - larva of third instar; L2 - larva of second instar.

Eleven specimens of Oreodytes sanmarkii were also found at eight sites. Stictotarsus griseostriatus (DeGeer) specimens were collected in three of the sites, but there was only a single specimen in each collection. The remaining species were all restricted to a single site each. Although several specimens of individual species were often found, for example, the sites with Agabus confinis (Gyllenhal) and A. arcticus (Paykull) (Table 1).

These collections are range extensions among the provinces and ecozones of Canada for most of the species collected, and represent a "filling in of gaps" in the distributions of many northern species. Because of logistic difficulties in sampling these interior regions of the arctic barrens, many previously reported species distributions have appeared disjunctive, or restricted to coastal areas (e.g., Larson et al. 2000). For example, the known ranges of Hydroporus appalachius Sherman, Oreodytes laevis, and Agabus confinis are extended to the northeast within the Northwest Territories, and those of Agabus arcticus and A. thomsoni Salhberg are extended to the northwest within Nunavut.
Oreodytes laevis and Hydroporus appalachius are widespread in the boreal low arctic zone of the Nearctic, so these records represent an extension into the Tundra zone. With respect to ecozone distribution, $O$. laevis, $H$. appalachius, and A. confinis are recorded for the first time from the Southern Arctic ecozone, and A. confinis is now known from all ecozones of Canada except the prairies. Ilybius erichsonii (Gemminger and Harold) is reported for the first time for Nunavut, and its known range is extended to the northeast within the Northwest Territories, and into the Southern Arctic Ecozone. Ilybius erichsonii has now been reported from all the ecozones of Canada. Hydroporus geniculatus Thomson is a Holarctic species which occurs in the boreal and alpine zones in northwestern North America. In Canada, it is distributed throughout most of British Columbia and western Alberta, and north into the Yukon Territory and Alaska (Larson et al. 2000), and is reported for the first time in this study in Nunavut and in the Southern Arctic ecozone. The present record is an extension of its known 
distribution far to the northeast, and therefore the range for this species appears disjunctive. However, $H$. geniculatus belongs to the poorly studied nigellusgroup, and revision of the group is needed to clarify its taxonomic position and distribution. We report the presence of Oreodytes sanmarkii in the Northwest Territories and in the Taiga Shield ecozone for the first time, and the collections along the Thelon River also represent the first record of the species on the Nunavut mainland. This Holarctic species was previously known in Canada from a few sites in northern Yukon and a site on Southampton Island (NU) (Larson et al. 2000). Hygrotus novemlineatus (Stephens), Hydroporus morio (Aubé), and Stictotarsus griseostriatus have been reported in the Canadian Barrens to the east and west of the sampled areas, but these collections indicate that their distributions are more continuous across the north than previous distribution maps might indicate. Gyrinus opacus (Gyrinidae) is reported for Nunavut for the first time, and collections on the Thelon River may represent the most northeasterly record for the species (Oygur and Wolfe 1991). However, this record is in need of confirmation since it is based on study of a single female specimen.

Most of the species were collected in habitats that matched those that were previously reported for each species (e.g., Larson et al. 2000). However, this study has produced some new and additional data on habitat distributions for several species. Oreodytes laevis and $O$. sanmarkii have been reported in rivers, streams, and along exposed shorelines of cold lakes with little or no submerged vegetation, and with mineral substrates. These two species dominated in these types of habitat along the Thelon and Horton rivers. According to Alarie and Maire (1991; as H. hudsonicus) and Larson et al. (2000), Hygrotus novemlineatus is circumpolar in the low arctic region and has been collected in Canada (near Churchill Manitoba, and in Quebec) in brackish splash pools (rock-pools) along the coast. However, in our survey it was collected among dense submerged grass in slow water current along the shore of the Thelon River. The species may have relatively wide habitat preferences, since Nilsson and Holmen (1995) reported it in Fennoscandia from similar habitats to the Thelon site, as well as from sandy oligotrophic lake margins and sparsely vegetated ponds. In the southern parts of its range, Hydroporus appalachius is usually found in habitats where there is some water movement, for example in streams, springs, and the margins of small lakes (Larson et al. 2000). In Labrador, the species was collected from a protected shoreline of a large lake (Larson et al. 2000), and it has been found in inland pools in the Quebec subarctic region (Alarie and Maire 1991). The habitat in the more northern parts of its range has not previously been described, and in this survey, it was found in small tundra pools that drained into each other before spilling into the Thelon River.

\section{Acknowledgments}

We are grateful to Rob Roughley and Lisa Purcell for their advice and comments on the manuscript. Financial support for the collections was provided by an NSERC operating grant, a UPEI Senate Research Grant, and a Nature Discovery Grant (National Museums of Canada) to D. J. Giberson. Lisa Purcell helped to collect the specimens. Support for the study of the material was provided by NSERC through a 2001 NATO Science Fellowship to H. V. Shaverdo and an NSERC operating grant to Rob Roughley. Voucher specimens have been deposited in the J. B. Wallace Museum of the University of Manitoba, the Royal Ontario Museum, and in the private collection of H. V. S. Collecting permits were provided by the territorial governments through the Aurora Research Institute in the Northwest Territories and the Nunavut Research Institute in Nunavut.

\section{Literature Cited}

Alarie, Y., and A. Maire. 1991. The dytiscid fauna of Québec Subarctic (Coleoptera: Dytiscidae). Coleopterists Bulletin 45: 350-357.

Anderson, R. S. 1997. An Overview of the Beetles (Coleoptera) of the Yukon. Pages 405-444 in Insects of the Yukon. Edited by H.V. Danks and J.A. Downes. Biological Survey of Canada. Monograph series (2), Biological Survey of Canada (Terrestrial Arthropods). Ottawa. Ontario.

Currie, D. C., D. J. Giberson, and B. V. Brown. 2000. Insects of Keewatin and Mackenzie. Newsletter of the Biological Survey of Canada (Terrestrial Arthropods) 19: 48-51.

Currie, D. C., D. J. Giberson, and B. V. Brown. 2002. Insect biodiversity in the Thelon Wildlife Sanctuary. Newsletter of the Biological Survey of Canada (Terrestrial Arthropods) 21: 59-64.

Ecological Stratification Working Group. 1995. A National Ecological Framework for Canada. Agriculture and AgriFood Canada, Research Branch, Centre for Land and Biological Resources Research, and Environment Canada, State of the Environment Directorate, Ecozone Analysis Branch, Ottawa/Hull. Report and national map at 1:7 500000 scale.

Larson, D. J. 1991. A new species of Potamonectes Zimmermann (Coleoptera: Dytiscidae) from Labrador. Coleopterists Bulletin 45: 280-284.

Larson, D. J. 1997. Dytiscid Water Beetles (Coleoptera: Dytiscidae) of the Yukon. Pages 491-522 in Insects of the Yukon. Edited by H. V. Danks and J. A. Downes. Biological Survey of Canada. Monograph series (2), Biological Survey of Canada (Terrestrial Arthropods). Ottawa. Ontario.

Larson, D. J., and R. E. Roughley. 1991. Family Dytiscidae. Pages 62-72 in Checklist of beetles of Canada and Alaska. Edited by Y. Bousquet. Agriculture Canada Publication 1861/E.

Larson, D. J., Y. Alarie, and R. E. Roughley. 2000. Predaceous Diving Beetles (Coleoptera: Dytiscidae) of the Nearctic Region, with emphasis on the fauna of Canada and Alaska. NRC Research Press, Ottawa, Ontario, Canada. 982 pages.

Nilsson, A. N., and M. Holmen. 1995. The aquatic Adephaga (Coleoptera) of Fennoscandia and Denmark. II. Dytiscidae. Fauna Entomologica Scandinavica 32: 1-192. 
Oygur, S., and G. W. Wolfe. 1991. Classification, distribution, and phylogeny of North American (north of Mexico) species of Gyrinus Müller (Coleoptera: Gyrinidae). Bulletin of the American Museum of Natural History 207: 1-97.
Roughley, R. E. 1991. Family Gyrinidae. Pages 72-73 in Checklist of beetles of Canada and Alaska. Edited by Y. Bousquet. Agriculture Canada Publication 1861/E.

Received 2 June 2003

Accepted 14 July 2004 